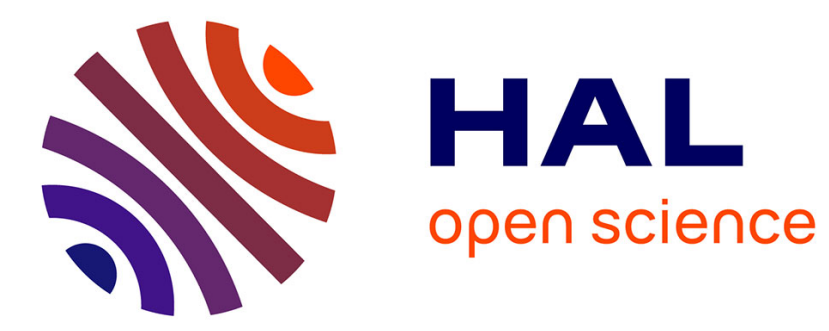

\title{
Weather-index drought insurance: an ex ante evaluation for millet growers in Niger
}

Antoine Leblois, Philippe Quirion

\section{To cite this version:}

Antoine Leblois, Philippe Quirion. Weather-index drought insurance : an ex ante evaluation for millet growers in Niger. 2011. hal-00866438

\section{HAL Id: hal-00866438 \\ https://hal.science/hal-00866438}

Preprint submitted on 30 Sep 2013

HAL is a multi-disciplinary open access archive for the deposit and dissemination of scientific research documents, whether they are published or not. The documents may come from teaching and research institutions in France or abroad, or from public or private research centers.
L'archive ouverte pluridisciplinaire HAL, est destinée au dépôt et à la diffusion de documents scientifiques de niveau recherche, publiés ou non, émanant des établissements d'enseignement et de recherche français ou étrangers, des laboratoires publics ou privés. 


\section{DOCUMENTS DE TRAVAIL / WORKING PAPERS}

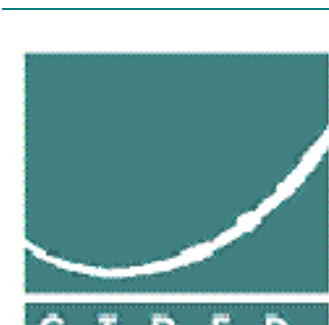

C.I.R.E.D.

No 27-2011

Weather-index drought insurance:

an ex ante evaluation for millet growers in Niger

Antoine Leblois

Philippe Quirion

February 2011

\section{C.I.R.E.D.}

Centre International de Recherches sur l'Environnement et le Développement UMR 8568 CNRS / EHESS / ENPC / ENGREF

/ CIRAD / METEO FRANCE

45 bis, avenue de la Belle Gabrielle

F-94736 Nogent sur Marne CEDEX

Tel : (33) 143947373 / Fax : (33) 143947370

www.centre-cired.fr 



\begin{abstract}
In the Sudano-Sahelian region, which includes South Niger, the inter-annual variability of the rainy season is high and irrigation is scarce. As a consequence, bad rainy seasons have a massive impact on crop yield and regularly entail food crises. Traditional insurances based on crop damage assessment are not available because of asymmetric information and high transaction costs compared to the value of production. We assess the risk mitigation capacity of an alternative form of insurance which has been implemented in India since 2003: insurance based on a weather index. We compare the capacity of various weather indices to increase utility of a representative risk-averse farmer. We show the importance of using plot-level yield data rather than village averages, which bias results. We also illustrate the need for out-of-sample estimations in order to avoid overfitting. Even with the appropriate index and assuming a substantial risk aversion, we find a limited gain of implementing insurance, roughly corresponding to, or slightly exceeding, the cost of implementing such insurances observed in India. However, when we treat separately the plots with and without fertilizers, we show that the benefit of insurance is higher in the former case. This suggests that insurances may increase the use of risk-increasing inputs like fertilizers and improved cultivars, hence average yields, which are very low in the region.
\end{abstract}

Keywords : Agriculture, weather index-based insurance, heterogeneity.

Potentiel d'une assurance contre la sécheresse pour les producteurs: évaluation ex ante dans le cas du mil au Niger.

\title{
Résumé
}

La variabilité interannuelle des pluies est importante au sud-ouest du Niger et dans l'ensemble du climat soudano-sahélien où l'irrigation est très rarement utilisée. Les mauvaises saisons ont donc un impact massif sur les rendements et déclenchent généralement des crises alimentaires. Les assurances traditionnelles fondées sur le niveau de pertes de production sont coûteuses en raison de l'asymétrie d'information et des coûts de transaction élevés, surtout au regard de la valeur de la production. Nous évaluons la capacité de mutualisation du risque de production d'assurances fondées sur des indices météorologiques, à l'instar de ceux mis en œuvre en Inde depuis 2003. Nous comparons les potentiels d'indices plus ou moins complexes dans cet objectif en mettant en avant la nécessité d'utiliser des données à l'échelle de la parcelle dans le calcul de revenus équivalents certains pour des producteurs ayant de l'aversion au risque. Nous montrons aussi bien la nécessité de prendre en compte le risque d'overfitting lors d'études ex ante. Bien qu'étant en partie à l'origine de la capacité de mutualisation des revenus agricoles, l'importante variabilité spatiale du climat dans cette zone est, en effet, aussi source d'hétérogénéité de la relation entre rendement et indices. Nous estimons finalement que le gain et le coût de mise en œuvre d'un tel contrat d'assurance, issu d'une initiative purement privée qui a eu lieu en Inde, sont d'une échelle comparable. L'impact réel de ces mécanismes privés de mutualisation du risque peut toutefois être amélioré par l'incitation à utiliser des intrants coûteux qu'ils créent. Nous montrons en effet que l'impact d'une assurance sur le revenu équivalent certain est supérieur pour les parcelles fertilisées. Ce gain est généré par la présence d'aversion au risque, souvent décrite comme une cause majeure du bas niveau d'intensification de l'agriculture en Afrique.

Mots-clés: Assurance paramétrique, hétérogénéité des rendements. 



\title{
Weather-index drought insurance for millet growers in Niger: an ex ante evaluation
}

\author{
Antoine Leblois* \& Philippe Quirion ${ }^{\dagger}$
}

January 2011

\begin{abstract}
In the Sudano-Sahelian region, which includes South Niger, the inter-annual variability of the rainy season is high and irrigation is scarce. As a consequence, bad rainy seasons have a massive impact on crop yield and regularly entail food crises. Traditional insurances based on crop damage assessment are not available because of asymmetric information and high transaction costs compared to the value of production. We assess the risk mitigation capacity of an alternative form of insurance which has been implemented in India since 2003: insurance based on a weather index. We compare the capacity of various weather indices to increase utility of a representative risk-averse farmer. We show the importance of using plot-level yield data rather than village averages, which bias results. We also illustrate the need for out-of-sample estimations in order to avoid overfitting. Even with the appropriate index and assuming a substantial risk aversion, we find a limited gain of implementing insurance, roughly corresponding to, or slightly exceeding, the cost of implementing such insurances observed in India. However, when we treat separately the plots with and without fertilizers, we show that the benefit of insurance is higher in the former case. This suggests that insurances may increase the use of risk-increasing inputs like fertilizers and improved cultivars, hence average yields, which are very low in the region.
\end{abstract}

Keywords: Agriculture, index insurance.

JEL Codes: G21, O12, Q12, Q18, Q54.

* CIRED (Centre International de Recherche sur l'Environnement et le Développement), leblois@centrecired.fr

† CIRED, LMD (Laboratoire de Météorologie Dynamique), Paris. 


\section{Introduction}

Since the 1970s, Sahel, including Niger, has suffered from severe droughts which have triggered important food crises (in particular in 1973, 1984 and 1991, and more recently in 2005, 2009 and 2010). To quote the UNDP 2008 Human Development Report, "During 2004 and 2005 the implications of these underlying vulnerabilities were powerfully demonstrated by a climate shock, with an early end to rains and widespread locust damage" (UNDP, 2008, chapter 2).

Traditional agricultural insurance, based on damage assessment cannot efficiently shelter farmers because they suffer from an information asymmetry between the farmer and the insurer, creating moral hazard situations and thus a need for costly damage assessment. An emerging alternative is insurance based on a weather index, which is used as a proxy for crop yield. In such a scheme, the farmer, in a given geographic area, pays an insurance premium every year, and receives an indemnity if the weather index of this area falls below a determined level (the strike). Index-based insurance does not suffer from the two abovementioned shortcomings: the weather index provides an objective, and relatively inexpensive, proxy of crop damages. However, its weakness is the basis risk, i.e., the imperfect correlation between the weather index and the yields of farmers contracting the insurance. The basis risk can be considered as the sum of two risks: first, the risk resulting from the index not being a perfect predictor of yield in general (the model basis risk). Second, the spatial basis risk: the index may not capture the weather effectively experienced by the farmer; all the more that the farmer is far from the weather station(s) that provide data on which index is calculated.

Very few articles in peer reviewed journals have investigated the impact of crop insurance based on weather index in developing or transition countries (Berg et al., 2009 in Burkina Faso, Breustedt et al., 2008 in Ukraine, Chantarat et al., 2008 in Kenya, Molini et al., 2008 in Ghana and Zant, 2008 in India). Ex-post studies (Hill and Viceisza, 2010; Cole et al. 2009; Gine and Yang, 2009 and Gine, Townsend, and Vickery 2008) are also quite limited due to the recent development of such products. However, many recent reports and working papers inquired such topic (Hellmut et al., 2009; Hazell et al., 2010 that exhaustively lists recent index insurance programmes and Leblois and Quirion, 2010), one even only concerns West Africa (DeBock, 2010).

This article aims at quantifying the benefit, more precisely the risk pooling capacity, of a rainfall index-based insurance. We take benefit of a recent database of plot-level yield observations matched with a high density rain gauge network. We show that using a plot-level yield distribution improves the reliability of the estimates, compared to using village yield averages. We also demonstrate, in this particular case, the necessity to run out-of-sample estimations of the insurance impact in order to control for overfitting. Finally, the database allows us to distinguish between traditional and intensified plots and to test whether the insurance may encourage growers to use more fertilisers.

The rest of the article is organised as follows: we first describe the data and methods (section 2), then the results (section 3), and a final fourth section concludes. 


\section{Data and method}

\section{$2.1 \quad$ Study area}

Niger is the third producer of millet in the world, succeeding to India and Nigeria. Millet covers more than $70 \%$ of its cultivation surface dedicated to cereal (FAO, 2010) and is almost only produced for internal consumption. The prevalence of millet, especially the traditional Haini Kiere cultivar, the one studied in this article, is due to its resistance to drought. Nevertheless, the dryness of the region, in a context of largely non-irrigated agriculture, suggests that water availability is one of the major factors limiting millet yields.

We study the Niamey squared degree area, because it is equipped with an exceptionally high density network of meteorological stations. Such infrastructure is needed in a region where spatial variability of rainfall is significantly high. We also dispose of six years (20042009) of yields and other precise agronomic data in ten villages. Yield observations have been collected by Agrhymet for a minimum of 30 growers in each village. Every plot is situated at less than 3 kilometres away from the nearest meteorological station, which is likely to limit the spatial basis risk mentioned above. In 2004, all plots were cultivated under traditional technical itineraries. In particular, very few mineral fertilizers, chemical herbicides or pesticides were used. From 2005 onwards, growers have continued to follow this traditional technical itinerary on a first plot but have freely received mineral fertilisers for applications in a second plot together with agronomical and technical advices from surveyors.

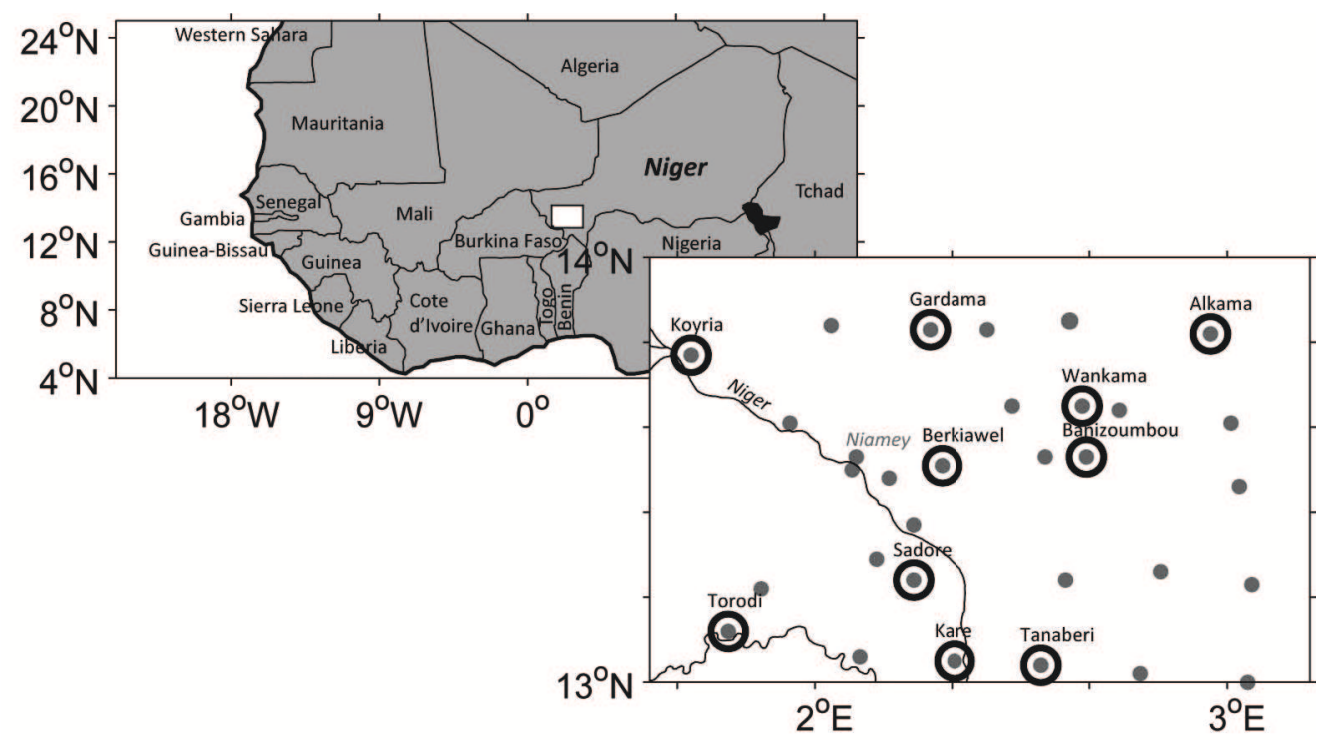

Figure 1: Rain gauges (all dots) and inquired villages (circled in black) network across Niamey Squared Degree.

Table 1 displays the summary statistics of the first plots, i.e. on which the traditional itinerary is followed, that includes $29 \%$ of organic fertilization and $11 \%$ of the growers sample using either only mineral or both organic and mineral fertilisers together. There is a high annual variability of yields across villages $\left(\mathrm{CV}^{1}=.4\right)$. Intra-village annual yield variation is

\footnotetext{
${ }^{1}$ Coefficient of variation: std. dev. on mean.
} 
however also quite significant $(\mathrm{CV}=.35)$, inducing a likely basis risk. It is due to a significant occurrence of idiosyncratic shocks, for a large part explained by insects ravages that account for more than $80 \%$ of all surveyed non-water-related damages ${ }^{2}$ that hit $50 \%$ of the whole surveyed growers sample.

Table 1: Summary statistics: regular plots (2004-2009)

\begin{tabular}{lccccc}
\hline \hline \multicolumn{1}{c}{ Variable } & Mean & Std. Dev. & Min. & Max. & N \\
\hline Farm Yields (kg/ha) & 606.39 & 395.25 & 0 & 3100 & 1616 \\
On-farm income (FCFA/ha) & 106919.85 & 69297.14 & 0 & 565421.19 & 1616 \\
Organic fertilization (1 if yes) & 0.29 &. & 0 & 1 & 1616 \\
Mineral fertilization (1 if yes) & 0.05 &. & 0 & 1 & 1616 \\
Both fertilization (1 if yes) & 0.06 &. & 0 & 1 & 1616 \\
\hline \hline 2 Authors calculations, cf. section 2.3 & & &
\end{tabular}

\section{$2.2 \quad$ Indemnity schedule}

Insurance indemnities are triggered by low values of an underlying index that is supposed to explain yield variation. The indemnity is a step-wise linear function of the index with 3 parameters: the strike $(\mathrm{S})$, i.e. the threshold triggering indemnity; the maximum indemnity (M) and $\lambda$, the slope-related parameter. When $\lambda$ equals one, the indemnity is either M (when the index falls below the strike level) or 0 . The strike represents the level at which the meteorological factor becomes limiting. We thus have the following indemnification function depending on $x$, the meteorological index realisation:

$$
I(S, M, \lambda, x)= \begin{cases}M, & \text { if } x \leq \lambda . S \\ \frac{S-x}{S-\lambda . S}, & \text { if } \lambda . S<x<S \\ 0, & \text { if } x \geq S\end{cases}
$$

\subsection{Index choice}

We first review different indices that could be used in a weather-index insurance, from the simplest to more complex ones. We tested the number of big rains (defined as superior to 15 and $20 \mathrm{~mm}$.) often quoted by farmers (Roncoli et al., 2002) as a good proxy of yields, the number of dry spell episodes in the season, Effective Drought Index (EDI, Byun and Wilhite, 1999) computed on a decadal basis and the Antecedent Precipitation Index (API, Shinoda et al., 2000) calibrated on a close area with similar characteristics than our study site (Yamagushi and Shinoda, 2002). Those indices are not presented in the paper because they were quite poor in terms of pooling capacity.

The indices considered in the paper are listed below by increasing complexity:

The first is the cumulative rainfall (referred to as $C R$ in the paper) over the crop growth period cutting off low daily precipitations $(<.85 \mathrm{~mm}$. following Odekunle, 2004) that are probably entirely evaporated. Using the actual sowing date to determine the beginning of

\footnotetext{
${ }^{2}$ Their occurrence is not significantly correlated with rainfall during the cropping season.
} 
the crop growth period in an insurance contract is difficult because it cannot be observed costlessly by the insurer. Thus we compare two growth phase schedules (the one observed referred to as obs and the one simulated following Sivakumar, 1988 rainy season criteria, defining the beginning and the end of the growing season; it is referred to as siva in the paper).

We then consider an improvement (referred to as BCR) of each of those simple indices by bounding daily rainfall at $30 \mathrm{~mm}$. corresponding to an excess of water that is not used by the crop.

Table 2: Summary statistics: growing season rainfall indices (2004-2009)

\begin{tabular}{lccccc}
\hline \hline \multicolumn{1}{c}{ Variable } & Mean & Std. Dev. & Min. & Max. & N \\
\hline$C R_{\text {obs }}(\mathrm{mm})$. & 480.36 & 91.70 & 263.816 & 735.89 & 1616 \\
$B C R_{\text {obs }}(\mathrm{mm})$. & 422.77 & 71.58 & 262.199 & 574.062 & 1616 \\
$C R_{\text {siva }}(\mathrm{mm})$. & 458.60 & 121.14 & 61.47 & 685.20 & 1616 \\
$B C R_{\text {siva }}(\mathrm{mm})$. & 404.61 & 103.90 & 61.47 & 565.47 & 1616 \\
$W A C R_{\text {siva }}$ & 277.83 & 74.86 & 33.54 & 453.57 & 1616 \\
$W A B C R_{\text {siva }}$ & 244.62 & 63.89 & 33.54 & 365.54 & 1616 \\
\hline \hline
\end{tabular}

A further complexification is to distinguish various phases during the crop growth period in the calculation of the index. Hence we use a weighted average of crop growth phases cumulative rainfall following Alhassane (1999) and Dancette (1983) weighting factors on the simulated crop growth phase. The indices are referred to as $W A C R$ when daily rainfall is not bounded and $W A B C R$ when it is. Table 2 displays the descriptive statistics of the abovementioned indices over the study period. The trade-off between accuracy and simplicity of the index, brought up by an emerging literature (Patt et al., 2009), would suggest to use the most transparent index among indices reaching similar outcomes.

\subsection{Parameter optimization}

We used a grid optimization process to maximize the objective function. The literature brought multiple different objective functions such as the semi variance (or downside risk as used in Vedenov and Barnett, 2004) or the mean-variance criterion. The former only takes risk into account, without considering the average consumption level. It is thus useful in order to calibrate an insurance contract but insufficient for assessing growers utility gain from insurance when considering its implementation costs. The mean-variance criterion accounts for both the consumption level and the risk, but it weights risk with an ad-hoc parameter. We finally retained the power or Constant Relative Risk Aversion (CRRA) utility function in order to compute the certain equivalent income (CEI) and value overall insurance gain. Power utility functions have the advantage to facilitate comparison for different risk aversions. CRRA appears appropriate to describe farmers' behaviours according to Chavas and Holt, 1996 or Pope and Just, 1991. We thus consider the following objective function:

$$
C E I(Y)=\left((1-\rho) \times E\left[\frac{\left(W_{0}+Y\right)^{(1-\rho)}}{(1-\rho)}\right]\right)^{\frac{1}{1-\rho}}-W_{0}
$$


$Y$ is the yield distribution, $W_{0}$ the initial wealth (representing off- and non-farm revenues, about 40 to $60 \%$ of total revenues according to Abdoulaye and Sanders, 2006) and $\rho$ the relative risk aversion parameter.

Adding a certain income $\left(W_{0}\right)$, the initial wealth, allows the premium to be superior to the lowest yield observation. It lowers the gain from insurance in term of certain equivalent income by increasing the certain part of total income. We set $W_{0}$ at a third of the average yield (216 kg of millet); lower than the rate proposed by Abdoulaye and Sanders, 2006, since those revenues probably also show some uncertainty. However, the results are robusts to significant variations of this parameter. We tested a range of values for the relative risk aversion parameter from .5 to 4 . This range encompasses the values usually used in the development economics literature (Coble et al., 2004; Wang et al., 2004; Carter et al., 2007 and Fafchamps, 2003; see Cardenas and Carpenter, 2008 for a review of econometric studies that estimates this parameter). A relative risk aversion of 4 may seem high but empirical estimates of relative risk aversion indicate a wide variation across individuals; therefore, if insurance is not compulsory, only the most risk-averse farmers are likely to be insured (Gollier, 2004).

We used yields (in kg per ha) as income variable for each observed plot regrouping the 10 villages during 4 consecutive years. Since the use of costly inputs such as mineral fertilisers is very limited ${ }^{4}$ and because a major part of the harvest is used for self consumption, with limited associated price risk, yield in $\mathrm{kg} / \mathrm{ha}$ is considered a satisfying proxy for on-farm revenue. The insurance contract parameters $S, M$ and $\lambda$ are optimized in order to maximize the certain equivalent income of equation (2) with the following income after insurance:

$$
Y_{i}=Y-P\left(S^{*}, M^{*}, \lambda^{*}, x\right)+I\left(S^{*}, M^{*}, \lambda^{*}, x\right)
$$

$Y_{i}$ is the income after indemnification, $Y$ the income before insurance, $P$ the premium, $I$ the indemnity and $x$ the rainfall index realisations associated with each plot. We bounded the premium to the minimum endowments, in accordance to the choice of the power utility function, only defined on $R^{+}$. A loading factor is defined as a percentage of total indemnifications on the whole period (fixed at $10 \%$ following a private experiment that took place in India, cf. section 3.4) and a transaction cost for each indemnification is fixed exogenously to one percent of the average yield. We finally bounded the indemnification rate to a $25 \%$ ad-hoc level.

\section{Results}

For the first two parts of this section we will only consider regular plots (921 observations), on which traditional technical itineraries are followed. The last part will compare different technical itineraries for the 2005-2009 sub-period for which data for both plots (regular and encouragement) are available.

\footnotetext{
${ }^{4}$ Plots with encouragement to fertilize use as well as on-farm income will be considered in the section 3.3 .
} 


\subsection{Plot-level vs. aggregated data}

Calibration on the whole sample allows taking intra-village yield variation into consideration, which is rarely the case in such studies due to a lack of plot level data. In tables 3 , 4, and 5 we present for each index the average grower's gain from insurance in certain equivalent income, respectively for. We estimate the optimal calibration of contract parameters, taking the whole sample into account in the first place (Table 3). Then we calibrated parameters of the insurance policy on the village average yields (Table 4) and we finally calibrate them on the village average yields and test them on the whole sample (Table 5). Insurance parameters depending on risk aversion in each index and in each of those 3 cases are displayed in the Annex.

Table 3: Average income gain of index insurance calibrated on the whole sample

\begin{tabular}{lccccc}
\hline \hline & $\rho=.5$ & $\rho=1$ & $\rho=2$ & $\rho=3$ & $\rho=4$ \\
\hline CEI gain of $C R_{\text {obs }}$ & $0.00 \%$ & $0.24 \%$ & $1.11 \%$ & $2.61 \%$ & $4.70 \%$ \\
CEI gain of $B C R_{\text {obs }}$ & $0.00 \%$ & $0.34 \%$ & $1.63 \%$ & $3.48 \%$ & $5.80 \%$ \\
CEI gain of $C R_{\text {siva }}$ & $0.00 \%$ & $0.34 \%$ & $1.47 \%$ & $3.00 \%$ & $4.91 \%$ \\
CEI gain of $B C R_{\text {siva }}$ & $0.00 \%$ & $0.33 \%$ & $1.75 \%$ & $3.76 \%$ & $6.44 \%$ \\
CEI gain of $W A C R_{\text {siva }}$ & $0.00 \%$ & $0.46 \%$ & $1.98 \%$ & $3.95 \%$ & $6.40 \%$ \\
CEI gain of $W A B C R_{\text {siva }}$ & $0.00 \%$ & $0.46 \%$ & $1.98 \%$ & $3.95 \%$ & $6.40 \%$ \\
\hline \hline
\end{tabular}

Table 4: Average income gain of index insurance calibrated on village average yields values

\begin{tabular}{llllll}
\hline \hline & $\rho=.5$ & $\rho=1$ & $\rho=2$ & $\rho=3$ & $\rho=4$ \\
\hline CEI gain of $C R_{\text {obs }}$ ins. & $0.00 \%$ & $0.24 \%$ & $1.17 \%$ & $2.68 \%$ & $4.70 \%$ \\
CEI gain of $B C R_{\text {obs }}$ ins. & $0.00 \%$ & $0.28 \%$ & $1.49 \%$ & $3.18 \%$ & $5.39 \%$ \\
CEI gain of $C R_{\text {siva }}$ ins. & $0.09 \%$ & $0.47 \%$ & $1.42 \%$ & $2.55 \%$ & $4.48 \%$ \\
CEI gain of $B C R_{\text {siva }}$ ins. & $0.00 \%$ & $0.17 \%$ & $1.22 \%$ & $2.71 \%$ & $4.67 \%$ \\
CEI gain of $W A C R_{\text {siva }}$ ins. & $0.00 \%$ & $0.40 \%$ & $1.77 \%$ & $3.50 \%$ & $5.63 \%$ \\
CEI gain of $W A B C R_{\text {siva }}$ ins. & $0.00 \%$ & $0.40 \%$ & $1.77 \%$ & $3.50 \%$ & $5.63 \%$ \\
\hline \hline
\end{tabular}

Table 5: Average income gain of index insurance calibrated on village average yields values and tested on the whole sample

\begin{tabular}{|c|c|c|c|c|c|}
\hline & $\rho=.5$ & $\rho=1$ & $\rho=2$ & $\rho=3$ & $\rho=4$ \\
\hline CEI gain of $C R_{o b s}$ ins. & ${ }^{\prime}$ & $0.23 \%$ & $0.93 \%$ & $1.78 \%$ & $2.89 \%$ \\
\hline CEI gain of $B C R_{o b s}$ ins. & . & $0.32 \%$ & $1.52 \%$ & $3.35 \%$ & $5.79 \%$ \\
\hline CEI gain of $C R_{\text {siva }}$ ins. & $-0.12 \%$ & $0.18 \%$ & $1.08 \%$ & $2.38 \%$ & $-2.39 \%$ \\
\hline CEI gain of $B C R_{\text {siva }}$ ins. & . & $0.33 \%$ & $1.75 \%$ & $3.74 \%$ & $6.18 \%$ \\
\hline CEI gain of $W A C R_{\text {siva }}$ ins. & . & $0.46 \%$ & $1.95 \%$ & $3.83 \%$ & $6.02 \%$ \\
\hline CEI gain of $W A B C R_{\text {siva }}$ ins. & . & $0.46 \%$ & $1.95 \%$ & $3.83 \%$ & $6.02 \%$ \\
\hline \multicolumn{6}{|c|}{ Variations in CEI gain (compared to calibration on the whole sample) } \\
\hline$C R_{\text {obs }}$ ins. & . & $-3.42 \%$ & $-15.79 \%$ & $-31.88 \%$ & $-38.48 \%$ \\
\hline$B C R_{o b s}$ ins. & . & $-5.76 \%$ & $-6.50 \%$ & $-3.92 \%$ & $-0.17 \%$ \\
\hline$C R_{\text {siva }}$ ins. & . & $-45.91 \%$ & $-26.56 \%$ & $-20.58 \%$ & ND\% \\
\hline$B C R_{\text {siva }}$ ins. & . & $-0.81 \%$ & $0.03 \%$ & $-0.54 \%$ & $-4.09 \%$ \\
\hline$W A C R_{\text {siva }}$ ins. & . & $0.00 \%$ & $-1.38 \%$ & $-3.01 \%$ & $-6.08 \%$ \\
\hline$W A B C R_{\text {siva }}$ ins. & . & $0.00 \%$ & $-1.38 \%$ & $-3.01 \%$ & $-6.08 \%$ \\
\hline
\end{tabular}

No insurance is supplied when assuming a low level of risk aversion (.5). The first result is that more complex indices generally lead to a larger gain: WACR provides a higher gain than 
BCR, which itself generally performs better than CR. The only exception is the WABCR index which provides the same outcome as the WACR index.

A second result is that the insurance gain is generally higher when dealing with simulated crop growth phase compared to observed ones. This results validate the use of simulated growth phase for index-based insurance products in the case of photoperiodic crops. Taking the average value for each village leads to a misestimation of insurance gain when computed with a concave utility function that depends on income distribution and sample size. In our case a misapprehension of village yield distribution therefore leads to a 'bad' calibration of insurance parameters (especially the maximum indemnification, that is found higher when calibrating on village averages, leading to an over-insurance situation, cf. Annex). The presence of village yield heterogeneity within villages modifies the effective gain of an insurance calibrated on village averages. We observe in Table 5 the lower gain from insurance when it is calibrated on village average yields, stemming from the high intra-village variations of yield. The average loss from average yield calibration is significant (15\%) but its size depends on the index. It stresses the usefulness to calibrate insurance parameters on observed yields at the plot level.

\subsection{Need for cross-validation}

In the previous section, we optimized the parameters and evaluated the insurance contracts on the same data. This creates a risk of overfitting due to the fact that parameters will not be calibrated and tested on the same data in an actual insurance implementation. We can identify such a phenomenon by running a cross-validation analysis (as do Vedenov and Barnett, 2004; Berg et al., 2009). We thus run a 'leave one (village) out' method, optimizing the 3 parameters of the insurance contract for each village using data from the 9 other villages, for each of the three different indices and on the whole sample of growers first plots. As showed by Figures 3, 4, 5, 6, 7 and 8 in the Annex, the strike level is relatively robust across out-of-sample estimations and comparable to the in-sample case. However the maximum indemnity $\mathrm{M}$ is less robust and we will show later that this will cause severe reductions in CEI gain.

In the out-of-sample estimations the insurer can be better off or worse off than in the corresponding contract optimized with the in-sample method ${ }^{5}$. Table 6 shows the gain in CEI when the insurer can either endure losses or benefits, due to the miscalibration that arises from the fact that insurance is assessed and calibrated on different datasets. It is thus important to keep in mind that in a real insurance project, either the insurer or the growers would suffer from this (partly unavoidable) miscalibration. In our case study, calibrating insurance parameters on the nine other villages leads, in most of the cases, to higher benefit for the insurer.

Table 7 shows the insurance gain in out-of-sample with a redistribution to growers of insurer profit (losses) that are superior (inferior) to the $10 \%$ charging rate we fixed in the previous sections. It allows the comparison with in-sample calibration estimates. The benefit

\footnotetext{
5 This is also the case in Berg et al. (2009, Fig. 4)
} 
Table 6: Average income gain of leave one (village) out calibration index insurance, with insurer gain or losses.

\begin{tabular}{|c|c|c|c|c|c|}
\hline & $\rho=.5$ & $\rho=1$ & $\rho=2$ & $\rho=3$ & $\rho=4$ \\
\hline CEI gain of $C R_{o b s}$ ins. & $0.72 \%$ & $-0.02 \%$ & $-1.48 \%$ & $-1.95 \%$ & $2.23 \%$ \\
\hline Insurer gain $(\mathrm{kg} / \mathrm{ha})$ with $C R_{\text {obs }}$ ins. & -3.55 & 2.01 & 8.03 & 8.42 & 4.28 \\
\hline Insurer gain (perc. of total indem.) with $C R_{o b s}$ ins. & $-82.95 \%$ & $18.27 \%$ & $45.46 \%$ & $49.88 \%$ & $20.57 \%$ \\
\hline CEI gain of $B C R_{o b s}$ ins. & $0.80 \%$ & $0.76 \%$ & $0.70 \%$ & $1.47 \%$ & $2.78 \%$ \\
\hline Insurer gain $(\mathrm{kg} / \mathrm{ha})$ with $B C R_{\text {obs }}$ ins. & -3.98 & -0.31 & 3.82 & 5.94 & 5.84 \\
\hline Insurer gain (perc. of total indem.) with $B C R_{o b s}$ ins. & $-61.75 \%$ & $-1.66 \%$ & $18.53 \%$ & $29.85 \%$ & $31.12 \%$ \\
\hline CEI gain of $C R_{\text {siva }}$ ins. & $0.69 \%$ & $-0.24 \%$ & $0.14 \%$ & $0.86 \%$ & $1.59 \%$ \\
\hline Insurer gain $(\mathrm{kg} / \mathrm{ha})$ with $C R_{\text {siva }}$ ins. & -3.83 & 3.17 & 3.80 & 4.05 & 3.66 \\
\hline Insurer gain (perc. of total indem.) with $B C R_{o b s}$ ins. & $-57.66 \%$ & $20.27 \%$ & $23.16 \%$ & $26.35 \%$ & $26.40 \%$ \\
\hline CEI gain of $B C R_{\text {siva }}$ ins. & $0.92 \%$ & $-0.22 \%$ & $1.19 \%$ & $2.47 \%$ & $3.99 \%$ \\
\hline Insurer gain $(\mathrm{kg} / \mathrm{ha})$ with $B C R_{\text {siva }}$ ins. & -4.96 & 3.96 & 3.18 & 4.36 & 4.63 \\
\hline Insurer gain (perc. of total indem.) with $B C R_{o b s}$ ins. & $-73.68 \%$ & $18.76 \%$ & $12.18 \%$ & $17.62 \%$ & $19.55 \%$ \\
\hline CEI gain of $W A C R_{\text {siva }}$ ins. & $0.80 \%$ & $0.05 \%$ & $1.10 \%$ & $1.98 \%$ & $3.77 \%$ \\
\hline Insurer gain $(\mathrm{kg} / \mathrm{ha})$ with $W A C R_{\text {siva }}$ ins. & -3.98 & 4.11 & 3.97 & 4.79 & 3.09 \\
\hline Insurer gain (perc. of total indem.) with $B C R_{o b s}$ ins. & $-61.75 \%$ & $16.01 \%$ & $14.01 \%$ & $18.66 \%$ & $12.56 \%$ \\
\hline CEI gain of $W A B C R_{\text {siva }}$ ins. & $0.00 \%$ & $-0.21 \%$ & $0.55 \%$ & $1.26 \%$ & $3.17 \%$ \\
\hline Insurer gain (kg/ha) with $W A B C R_{\text {siva }}$ ins. & 0.00 & 5.26 & 5.63 & 6.30 & 4.15 \\
\hline Insurer gain (perc. of total indem.) with $B C R_{o b s}$ ins. & . & $21.05 \%$ & $20.42 \%$ & $25.26 \%$ & $17.39 \%$ \\
\hline
\end{tabular}

Table 7: Average income gain of leave one (village) out calibration index insurance, with equal redistribution across growers of residual gains or losses from the charging rate (10\% of total indemnification) by the insurer.

\begin{tabular}{|c|c|c|c|c|c|}
\hline & $\rho=.5$ & $\rho=1$ & $\rho=2$ & $\rho=3$ & $\rho=4$ \\
\hline CEI gain of $C R_{o b s}$ ins. & $-0.02 \%$ & $0.16 \%$ & $0.15 \%$ & $0.21 \%$ & $3.06 \%$ \\
\hline CEI gain of $B C R_{o b s}$ ins. & $-0.06 \%$ & $0.31 \%$ & $1.15 \%$ & $2.69 \%$ & $4.27 \%$ \\
\hline CEI gain of $C R_{\text {siva }}$ ins. & $-0.14 \%$ & $0.10 \%$ & $0.69 \%$ & $1.65 \%$ & $2.46 \%$ \\
\hline CEI gain of $B C R_{\text {siva }}$ ins. & $-0.13 \%$ & $0.17 \%$ & $1.33 \%$ & $3.05 \%$ & $4.82 \%$ \\
\hline CEI gain of $W A C R_{\text {siva }}$ ins. & $-0.06 \%$ & $0.37 \%$ & $1.39 \%$ & $2.67 \%$ & $4.01 \%$ \\
\hline CEI gain of $W A B C R_{\text {siva }}$ ins. & $0.00 \%$ & $0.36 \%$ & $1.29 \%$ & $2.46 \%$ & $3.84 \%$ \\
\hline \multicolumn{6}{|c|}{ Loss in CEI gain (compared to the in-sample calibration) } \\
\hline$C R_{\text {obs }}$ ins. & . & $-32.13 \%$ & $-86.83 \%$ & $-92.08 \%$ & $-34.92 \%$ \\
\hline$B C R_{o b s}$ ins. & . & $-9.44 \%$ & $-21.79 \%$ & $-10.27 \%$ & $-13.10 \%$ \\
\hline$C R_{\text {siva }}$ ins. & 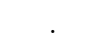 & $-71.07 \%$ & $-54.45 \%$ & $-50.82 \%$ & $-57.54 \%$ \\
\hline$B C R_{\text {siva }}$ ins. & . & $-49.20 \%$ & $-23.66 \%$ & $-18.90 \%$ & $-25.11 \%$ \\
\hline$W A C R_{\text {siva }}$ ins. & . & $-19.00 \%$ & $-29.90 \%$ & $-32.27 \%$ & $-37.45 \%$ \\
\hline$W A B C R_{\text {siva }}$ ins. & . & $-20.30 \%$ & $-35.00 \%$ & $-37.79 \%$ & $-39.99 \%$ \\
\hline
\end{tabular}

of insurance for growers drops by 9 to $92 \%$, with an average of $38 \%$, when keeping artificially the insurer out-of-sample gain equal to the in-sample case. The ranking of the indices is also changed: while $B C R_{\text {siva }}$ is still better than $C R_{\text {siva }}$, it is now generally also better than the more complex indices $W A C R_{\text {siva }}$ and $W A B C R_{\text {siva }}$.

\subsection{Potential intensification due to insurance}

As pointed out by Zant (2008), our ex ante approach does not take into account the potential intensification due to insurance supply. Indeed, many agricultural inputs, especially fertilisers, increase the average yield but also the risk. If the rainy season is bad, the farmer still has to pay for the fertilisers even though the increase in yield will be very limited or even nil. The literature on micro-insurance suggests that the supply of mitigating risk products 
could increase the incentive to use more intensive production, directly by lowering the level of risk faced by growers (Hill, 2010), or indirectly thanks to a higher credit supply at a lower rate (Dercon and Christiaensen, 2007).

Table 8: Summary statistics: all plots (2005-2009)

\begin{tabular}{|c|c|c|c|c|c|}
\hline Variable & Mean & Std. Dev. & Min. & Max. & $\mathbf{N}$ \\
\hline Farm Yields (kg/ha) & 583.39 & 379.81 & 0 & 3300 & 2632 \\
\hline On-farm income (FCFA) & 101900.38 & 69498.52 & -5013.55 & 592400 & 2632 \\
\hline$C R_{\text {obs }}(\mathrm{mm})$. & 476.70 & 95.97 & 293.37 & 735.89 & 2632 \\
\hline$B C R_{o b s}(\mathrm{~mm})$. & 423.70 & 74.37 & 281.15 & 574.06 & 2632 \\
\hline$C R_{\text {siva }}(\mathrm{mm})$. & 457.87 & 127.31 & 61.47 & 685.20 & 2632 \\
\hline$B C R_{\text {siva }}(\mathrm{mm})$. & 404.69 & 105.19 & 61.47 & 565.47 & 2632 \\
\hline$W A C R_{\text {siva }}$ & 280.36 & 80.32 & 33.54 & 453.57 & 2632 \\
\hline$W A B C R_{\text {siva }}$ & 245.24 & 67.92 & 33.54 & 365.54 & 2632 \\
\hline \multicolumn{6}{|l|}{ Among which } \\
\hline \multicolumn{6}{|l|}{ Regular plots: } \\
\hline Farm Yields (kg/ha) & 544.27 & 359.64 & 0 & 3100 & 1316 \\
\hline On-farm income (FCFA) & 98557.72 & 66446.75 & 0 & 565421.19 & 1316 \\
\hline \multicolumn{6}{|l|}{ Encouragement plots: } \\
\hline Farm Yields (kg/ha) & 622.51 & 395.24 & 31 & 3300 & 1316 \\
\hline On-farm income (FCFA) & 105243.04 & 72292.65 & -5013.55 & 592400 & 1316 \\
\hline
\end{tabular}

To address the first point we use additional data concerning 'encouragement' plots: where more inputs (micro-dose fertilization) are used because they were freely allocated by surveyors. Each grower has a 'regular' plot and an 'encouragement' plot, the latter being only available for the 2005-2009 period. Our hypothesis is the following: since the cost of a bad rainy season is higher for intensified production, insurance gain should be also higher. In such a case insurance should foster intensification and therefore bring a higher gain than with an exogenous level of fertilisers.

Table 8 displays the summary statistics of the indices over the sub-period considered in this section. We value production at the annual average market price of millet in Niamey, taken from SIM network ${ }^{6}$ in order to compute on-farm income for each plot. Fertilizers prices are taken from the 'Centrale d'Approvisionnement de la République du Niger'. Quantities are fixed to $50 \mathrm{~kg}$ per hectare, more than the minimal level required $(20 \mathrm{~kg} / \mathrm{ha})$ but less than the maximum (60 kg/ha) according to Abdoulaye and Sanders (2006) and to $25 \mathrm{~kg}$ per hectare for those using both organic and mineral fertilisers. Sensitivity to this parameter was run and showed no particular modification of the principal results. The benefit from using fertilisers without insurance is quite low when taking the input costs into account. Observed yields are about $14.4 \%$ higher in the plots where fertilization were encouraged. On-farm income of plots where organic, mineral or both fertilisers were used is about $6.8 \%$ superior in average but with higher risk compared to regular plots that were grown under traditional technical itineraries (corresponding to a CV increase of $2.7 \%$ in yield distribution of the second plot).

\footnotetext{
${ }^{6}$ Millet prices are the average prices of Niamey markets that are available each year; the SIM network is an integrated information network across 6 countries in West Africa (resimao.org).
} 
Table 9: In-sample average gain of insurance depending on the index and risk aversion parameter.

\begin{tabular}{lccccc}
\hline \hline & $\rho=.5$ & $\rho=1$ & $\rho=2$ & $\rho=3$ & $\rho=4$ \\
\hline All sample (N=2632) & & & & & \\
\hline$C R_{\text {obs }}$ & $0.00 \%$ & $0.37 \%$ & $1.83 \%$ & $3.88 \%$ & $6.45 \%$ \\
$B C R_{\text {obs }}$ & $0.00 \%$ & $0.40 \%$ & $1.84 \%$ & $3.98 \%$ & $6.78 \%$ \\
$C R_{\text {siva }}$ & $0.00 \%$ & $0.46 \%$ & $2.05 \%$ & $4.34 \%$ & $7.25 \%$ \\
$B C R_{\text {siva }}$ & $0.00 \%$ & $0.37 \%$ & $1.90 \%$ & $4.01 \%$ & $6.57 \%$ \\
$W A C R_{\text {siva }}$ & $0.00 \%$ & $0.34 \%$ & $1.86 \%$ & $3.91 \%$ & $6.42 \%$ \\
$W A B C R_{\text {siva }}$ & $0.00 \%$ & $0.34 \%$ & $1.86 \%$ & $3.91 \%$ & $6.42 \%$ \\
\hline Regular plots (N=1316) & & & & & \\
\hline$C R_{\text {obs }}$ & $0.00 \%$ & $0.13 \%$ & $1.05 \%$ & $2.27 \%$ & $3.70 \%$ \\
$B C R_{\text {obs }}$ & $0.00 \%$ & $0.36 \%$ & $1.52 \%$ & $3.05 \%$ & $4.90 \%$ \\
$C R_{\text {siva }}$ & $0.00 \%$ & $0.35 \%$ & $1.72 \%$ & $3.63 \%$ & $6.06 \%$ \\
$B C R_{\text {siva }}$ & $0.00 \%$ & $0.54 \%$ & $2.06 \%$ & $4.00 \%$ & $6.26 \%$ \\
$W A C R_{\text {siva }}$ & $0.00 \%$ & $0.34 \%$ & $1.75 \%$ & $3.53 \%$ & $5.60 \%$ \\
$W A B C R_{\text {siva }}$ & $0.00 \%$ & $0.34 \%$ & $1.75 \%$ & $3.53 \%$ & $5.60 \%$ \\
\hline Encouragement plots $(\mathrm{N}=1316)$ & & & & & \\
\hline$C R_{\text {obs }}$ & $0.00 \%$ & $0.62 \%$ & $2.62 \%$ & $5.50 \%$ & $9.04 \%$ \\
$B C R_{\text {obs }}$ & $0.00 \%$ & $0.44 \%$ & $2.16 \%$ & $4.90 \%$ & $8.50 \%$ \\
$C R_{\text {siva }}$ & $0.00 \%$ & $0.57 \%$ & $2.39 \%$ & $5.02 \%$ & $8.27 \%$ \\
$B C R_{\text {siva }}$ & $0.00 \%$ & $0.19 \%$ & $1.73 \%$ & $3.99 \%$ & $6.78 \%$ \\
$W A C R_{\text {siva }}$ & $0.00 \%$ & $0.35 \%$ & $1.96 \%$ & $4.28 \%$ & $7.10 \%$ \\
$W A B C R_{\text {siva }}$ & $0.00 \%$ & $0.35 \%$ & $1.96 \%$ & $4.28 \%$ & $7.10 \%$ \\
\hline \hline
\end{tabular}

Tables 9 displays the in-sample gain from insurance in FCFA for risk averse growers and risk neutral insurer. Gain from insurance is higher in the encouragement plots sample, due to a greater risk in income caused by costly input use.

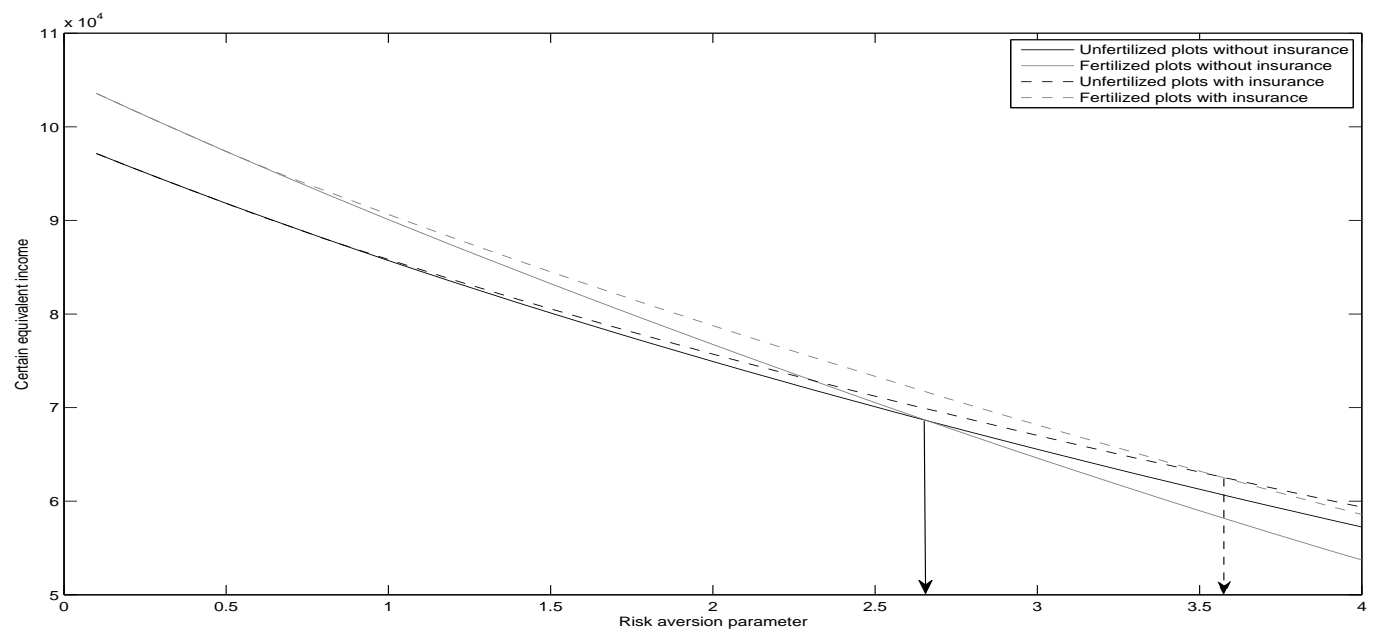

Figure 2: CEI without and with $C R_{\text {obs }}$ based insurance, depending on the risk aversion parameter, $\rho$, and technical itineraries.

Figures 2 displays the CEI level of an average grower depending on the risk aversion parameter and for both technical itineraries, for the $C R_{o b s}$ index. Similar figures for the other indices are reproduced in the Annex. Arrows shows the threshold level of risk aversion from which it is not interesting for growers to fertilise inputs anymore. Those figures underline the importance to take into account the higher incentive to use costly inputs when insurance 
is supplied. There is indeed more growers that will undertake fertilization and use costly inputs when insurance is supplied, modifying average yield and yield distribution. The ex post impact of insurance could thus be significantly higher that the one assessed ex ante.

\subsection{Comparison of cost and benefit of insurance}

A totally private experience has taken place since 2003 in 8 districts in India. About 10,000 insurance are now sold every year, based on a network of 40 weather stations, without subsidies (Horréard, et al., 2010). The average loss ratio for the 6 years is $65 \%$. The total cost is about US\$ 7000 per year (US\$1.3 per policy sold), among which $30 \%$ is dedicated to design and implementation (ICICI Lombard), another 30\% to reinsurance (SwissRe) and $40 \%$ to distribution (Basix); each of them showing about $10 \%$ benefits.

In our case a $1 \%$ increase in CEI can be valued at about US\$ 2 per hectare when millet is valorized at the period average price (SIM network cf. section 3.3) for the period considered. Given the distribution of income among traditional technical itineraries, the insurance gain should exceed $0.7 \%$ in order to be profitable to the whole system composed of growers and the insurer. We found in section 3.2 that the gain from insurance is limited in out-ofsample as compared to in-sample estimations. For most indices, the insurance is thus worth implementing if growers' risk aversion parameters is equal or superior to 2 .

Moreover we also showed in section 3.3 that insurance impact on CEI could be higher when production is intensified, when only considering intensive plots and reasonable risk aversion (say 2) and that a larger part of growers are up to use costly inputs. If insurance actually creates an incentive to intensification, its performance finally could become significant compared to its cost.

\section{Conclusions}

The article brings four major conclusions. First it underlines the need to use plot level data to study and get a robust estimation of the impact of insurance. In the case of millet in South West Niger, where intra-village yield variations are high and the causes of bad yields are numerous, the outcomes of relatively simple indices are comparable to those of more complex ones. More specifically, the better index (within an out-of-sample assessment) is a simple bounded cumulative rainfall over the growing period. This conclusion is welcome since a simple index is easier to understand for growers. Another welcome result is that indices based on a simulated sowing date perform at least as well as those based on observed sowing dates, that would be costly to collect. Out-of-sample estimations show that miscalibration is a risk for both the insurer or growers. We show that for the benefit from index-based insurance to e higher than its implementation cost, a rather high risk aversion (typically 2) is required. The last two results emphasize the need for more research in order to evaluate the potential of such products in the case of low intensification, showed by most food crop production systems in sub-Saharan Africa. It particularly emphasizes the need for 
an accurate index and precise calibration of insurance policy parameters on observed data in the particular case of millet in Niger.

We finally show that insurance supply could foster costly input use. Even if our ex ante estimation cannot rigorously take such impact into account, it suggests that the use of such financial risk transfer products should be accompanied with credit and/or input supply. As we showed, insurance outcome is more probably to be superior to its estimated cost when taking potential intensification into account since the latter increases the risk taken by growers.

Acknowledgements: We thank A. Alhassane and S. Traoré from Agrhymet for the data, P. Roudier for sowing dates calculations, J. Sanders for kindly providing input price series and R. Marteau for drawing the Niamey Squared Degree map.

\section{References}

Abdoulaye, T., And J. H. Sanders (2006): "New technologies, marketing strategies and public policy for traditional food crops: Millet in Niger," Agricultural Systems, 90(1-3), $272-292$.

AfFHolder, F. (1997): "Empirically modelling the interaction between intensification and climatic risk in semiarid regions," Field Crops Research, 52(1-2), 79-93, 0378-4290.

Alhassane, A. (2009): "Effet du climat et des pratiques culturales sur la croissance et le développement du mil (Pennisetum Glaucum) au Sahel: contribution à l'amélioration du modèle de prévision des rendements SARRA-H," Thèse Doc. physiologie végétale, spécialité : Agrométéorologie. Univ. de Cocody, Abidjan.

Allen, R., L. Pereira, D. Raes, and M. Smith (1998): "Crop evapo transpiration guidelines for computing crop water requirements," Discussion paper, FAO.

Berg, A., P. Quirion, and B. Sultan (2009): "Can weather index drought insurance benefit to Least Developed Countries' farmers? A case study on Burkina Faso," Weather, Climate and Society, 1, 7184.

Breustedt, G., R. Bokusheva, and O. Heidelbach (2008): "Evaluating the Potential of Index Insurance Scheme to Reduce Crop Yield Risk in an Arid Region," Journal of Agricultural Economics, 59(2), 312-328.

Byun, H. R., And D. K. LeE (2002): "Defining Three Rainy Seasons and the Hydrological Summer Monsoon in Korea using Available Water Resources Index," Journal of the Meteorological Society of Japan, 80(1), 33-44.

Byun, H. R., And D. A. Wilhite (1999): "Objective Quantification of Drought Severity and Duration," Journal of Climate, 12(9), 2747-2756. 
Cardenas, J.-C., And J. Carpenter (2008): "Behavioural Development Economics: Lessons from Field Labs in the Developing World," The Journal of Development Studies, $44(3), 311-338$.

Carter, M., F. Galarza, and S. Boucher (2007): "Underwriting area-based yield insurance to crowd-in credit supply and demand," Savings and Development, (3).

Chantarat, S., C. G. Turvey, A. G. Mude, and C. B. Barrett (2008): "Improving humanitarian response to slow-onset disasters using famine-indexed weather derivatives," Agricultural Finance Review, 68(1), 169-195.

Chavas, J. P., and M. Holt (1996): "Economic Behaviour under Uncertainty: A Joint Analysis of Risk Preference and Technology," Review of Economics and Statistics, 78(2), 329-335.

Coble, K. H., J. C. Miller, M. Zuniga, and R. Heifner (2004): "The joint effect of Government Crop Insurance and Loan Programmes on the demand for futures hedging," European Review Agricultural Economics, 31, 309-330.

Cole, S. A., X. Gine, J. B. Tobacman, P. B. Topalova, R. M. Townsend, and J. I. ViCKERY (2009): "Barriers to Household Risk Management: Evidence from India," SSRN eLibrary.

Cook, K. H., And E. K. Vizy (2006): "Coupled model simulations of the west African monsoon system : Twentieth- and twenty-first-century simulations," Journal of climate, 19(15), 3681-3703.

Dancette, C. (1983): "Estimation des besoins en eau des principales cultures pluviales en zone soudano-sahélienne," Agronomie Tropicale, 38(4), 281294.

De Bock, O. (2010): "Etude de faisabilité : Quels mécanismes de micro-assurance privilégier pour les producteurs de coton au Mali ?," Discussion paper, CRED, PlaNet Guarantee.

Dercon, S., and L. Christiaensen (2007): "Consumption Risk, Technology Adoption, and Poverty Traps: Evidence from Ethiopia," World Bank Policy Research Working Paper No 4257.

FAfChAmps, M. (2003): Rural poverty, risk and development. E. Elgar, Cheltenham, U.K., Includes bibliographical references (p. 227-255) and index. Accessed from http://nla.gov.au/nla.cat-vn3069448.

FEWSNET (2010): "Niger report," Accessed www.fews.net/pages/country.aspx?gb=ne\&l=en.

Giné, X., R. Townsend, And J. VickeRY (2008): "Patterns of Rainfall Insurance Participation in Rural India," World Bank Econ Rev, 22(3), 539-566. 
Giné, X., And D. YAng (2009): "Insurance, credit, and technology adoption: Field experimental evidence from Malawi," Journal of Development Economics, 89, 1-11, 0304-3878.

Gollier, C. (2004): The Economics of Risk and Time, vol. 1. The MIT Press, 1 edn.

Hazell, P., J. Anderson, N. Balzer, A. H. Clemmensen, U. Hess, and F. Rispoli (2010): "Potential for scale and sustainability in weather index insurance for agriculture and rural livelihoods," Discussion paper, International Fund for Agricultural Development and World Food Programme (IFAD).

Hellmuth, M., D. Osgood, U. Hess, A. Moorhead, and H. Bhojwani (2009): "Index insurance and climate risk: prospects for development and disaster management," Discussion paper, International Research Institute for Climate and Society (IRI), Climate and Society No. 2.

Horréard, G., B. Oggeri, I. Rozenkopf, A. Chetallle, A. Duffau, and D. LaGANDRÉ (2010): "Gestion de risques agricoles par les petits producteurs, focus sur l'assurance-récolte indicielle et le warrantage," Discussion paper, GRET.

Leblois, A., And P. Quirion (2010): "Agricultural Insurances Based on Meteorological Indices: Realizations, Methods and Research Agenda," Working Papers 2010.71, Fondazione Eni Enrico Mattei.

Molini, V., M. Keyzer, B. van Den Boom, And W. Zant (2008): "Creating Safety Nets Through Semi-parametric Index-Based Insurance: A Simulation for Northern Ghana," Agricultural Finance Review, 68(1), 223-246.

Odekunle, T. O. (2004): "Rainfall and the length of the growing season in Nigeria," International Journal of Climatology, 24(4), 467-479, 10.1007/s00704-005-0166-8.

Patt, A., N. Peterson, M. Carter, M. Velez, U. Hess, and P. Suarez (2009): "Making index insurance attractive to farmers," Mitigation and Adaptation Strategies for Global Change, 14(8), 737-753, 10.1007/s11027-009-9196-3.

Pope, R. D., And R. E. Just (1991): "On testing the structure of risk preferences in agricultural supply system," American Journal of Agricultural Economics, pp. 743-748.

Roncoli, C., K. Ingram, and P. Kirshen (2002): "Reading the rains: local knowledge and rainfall forescasting in Burkina Faso," Society and Natural Ressources, 15, 409-427.

Shinoda, M., Y. Yamaguchi, and H. Iwashita (2000): "A new index of the Sahelian soil moisture for climate change studies," Proc. Int. Conf. on Climate Change and VariabilityPast, Present and Future, Tokyo, Japan, International Geographical Union Commission on Climatology, p. 255260.

Sivakumar, M. V. K. (1988): "Predicting rainy season potential from the onset of rains in Southern Sahelian and Sudanian climatic zones of West Africa," Agricultural and Forest Meteorology, 42(4), 295 - 305. 
UNDP (2008): Human Development Report. Oxford University Press.

Vedenov, D. V., And B. J. Barnett (2004): "Efficiency of Weather Derivates as Primary Crop Insurance Instruments," Journal of Agricultural and Resource Economics, 29(3), $387-403$.

Wang, H. H., L. D. Makus, and C. X. (2004): "The impact of US Commodity Programmes on hedging in the presence of Crop Insurance," European Review Agricultural Economics, 31, 331-352.

Yamaguchi, Y., And M. Shinoda (2002): "Soil Moisture Modeling Based on Multiyear Observations in the Sahel," Journal of applied meteorology, 41(11), 1140-1146.

ZANT, W. (2008): "Hot Stuff: Index Insurance for Indian Smallholder Pepper Growers," World Development, 36(9), 1585-1606, 0305-750X.

\section{Annex}

\section{$5.1 \quad$ In-sample calibrations}

Table 10: Parameters calibration of index insurance policy calibrated on the whole sample

\begin{tabular}{|c|c|c|c|c|c|}
\hline & $\rho=.5$ & $\rho=1$ & $\rho=2$ & $\rho=3$ & $\rho=4$ \\
\hline \multicolumn{6}{|l|}{ Strike } \\
\hline$C R_{o b s}$ ins. & . & 370.52 & 399.23 & 399.23 & 399.23 \\
\hline$B C R_{o b s}$ ins. & . & 317.73 & 360.05 & 360.05 & 360.05 \\
\hline$C R_{\text {siva }}$ ins. & . & 349.94 & 349.94 & 349.94 & 349.94 \\
\hline$B C R_{\text {siva }}$ ins. & . & 320.12 & 320.12 & 320.12 & 323.32 \\
\hline$W A C R_{\text {siva }}$ ins. & . & 219.34 & 219.34 & 219.34 & 219.34 \\
\hline \multicolumn{5}{|l|}{ percentage of indemnified growers } & 197.07 \\
\hline$C R_{o b s}$ ins. & 0.00 & 0.08 & 0.20 & 0.20 & 0.20 \\
\hline$B C R_{o b s}$ ins. & 0.00 & 0.10 & 0.17 & 0.17 & 0.17 \\
\hline$C R_{\text {siva }}$ ins. & 0.00 & 0.12 & 0.12 & 0.12 & 0.12 \\
\hline$B C R_{\text {siva }}$ ins. & 0.00 & 0.17 & 0.17 & 0.17 & 0.19 \\
\hline$W A C R_{\text {siva }}$ ins. & 0.00 & 0.19 & 0.19 & 0.19 & 0.19 \\
\hline$W A B C R_{\text {siva }}$ ins. & 0.00 & 0.19 & 0.19 & 0.19 & 0.19 \\
\hline \multicolumn{6}{|l|}{$\lambda$ (slope related parameter) } \\
\hline$C R_{o b s}$ ins. & . & 1.00 & 1.00 & 1.00 & 1.00 \\
\hline$B C R_{o b s}$ ins. & . & 0.95 & 1.00 & 1.00 & 1.00 \\
\hline$C R_{\text {siva }}$ ins. & . & 1.00 & 1.00 & 1.00 & 1.00 \\
\hline$B C R_{\text {siva }}$ ins. & . & 1.00 & 1.00 & 1.00 & 1.00 \\
\hline$W A C R_{\text {siva }}$ ins. & . & 1.00 & 1.00 & 1.00 & 1.00 \\
\hline$W A B C R_{\text {siva }}$ ins. & . & 1.00 & 1.00 & 1.00 & 1.00 \\
\hline \multicolumn{6}{|l|}{ M (maximum indemnification) } \\
\hline$C R_{\text {obs }}$ ins. & . & 140.61 & 114.25 & 114.25 & 114.25 \\
\hline$B C R_{o b s}$ ins. & . & 149.40 & 140.61 & 131.82 & 131.82 \\
\hline$C R_{\text {siva }}$ ins. & . & 140.61 & 149.40 & 140.61 & 131.82 \\
\hline$B C R_{\text {siva }}$ ins. & . & 131.82 & 149.40 & 140.61 & 131.82 \\
\hline$W A C R_{\text {siva }}$ ins. & . & 140.61 & 149.40 & 140.61 & 131.82 \\
\hline$W A B C R_{\text {siva }}$ ins. & . & 140.61 & 149.40 & 140.61 & 131.82 \\
\hline
\end{tabular}


Table 11: Average income gain of index insurance calibrated on village average yields values

\begin{tabular}{|c|c|c|c|c|c|}
\hline & $\rho=.5$ & $\rho=1$ & $\rho=2$ & $\rho=3$ & $\rho=4$ \\
\hline \multicolumn{6}{|l|}{ Strike } \\
\hline$C R_{o b s}$ ins. & . & 370.46 & 395.87 & 395.87 & 388.98 \\
\hline$B C R_{o b s}$ ins. & 349.73 & 349.73 & 349.73 & 349.73 & 375.08 \\
\hline$C R_{\text {siva }}$ ins. & . & 359.00 & 359.00 & 359.00 & 359.00 \\
\hline$B C R_{\text {siva }}$ ins. & . & 319.79 & 319.79 & 319.79 & 319.79 \\
\hline$W A C R_{\text {siva }}$ ins. & . & 219.17 & 219.17 & 219.17 & 219.17 \\
\hline $\begin{array}{l}W A B C R_{\text {siva }} \text { ins. } \\
\text { percentage of indemnified growers }\end{array}$ & . & 196.92 & 196.92 & 196.92 & 196.92 \\
\hline$C R_{o b s}$ ins. & 0.00 & 0.07 & 0.20 & 0.20 & 0.17 \\
\hline$B C R_{o b s}$ ins. & 0.05 & 0.05 & 0.05 & 0.05 & 0.20 \\
\hline$C R_{\text {siva }}$ ins. & 0.00 & 0.15 & 0.15 & 0.15 & 0.15 \\
\hline$B C R_{\text {siva }}$ ins. & 0.00 & 0.17 & 0.17 & 0.17 & 0.17 \\
\hline$W A C R_{\text {siva }}$ ins. & 0.00 & 0.18 & 0.18 & 0.18 & 0.18 \\
\hline$W A B C R_{\text {siva }}$ ins. & 0.00 & 0.18 & 0.18 & 0.18 & 0.18 \\
\hline \multicolumn{6}{|l|}{$\lambda$ (slope related parameter) } \\
\hline$C R_{o b s}$ ins. & . & 1.00 & 1.00 & 1.00 & 1.00 \\
\hline$B C R_{o b s}$ ins. & 1.00 & 1.00 & 1.00 & 1.00 & 1.00 \\
\hline$C R_{\text {siva }}$ ins. & . & 1.00 & 1.00 & 1.00 & 1.00 \\
\hline$B C R_{\text {siva }}$ ins. & . & 1.00 & 1.00 & 1.00 & 1.00 \\
\hline$W A C R_{\text {siva }}$ ins. & . & 1.00 & 1.00 & 1.00 & 1.00 \\
\hline$W A B C R_{\text {siva }}$ ins. & . & 1.00 & 1.00 & 1.00 & 1.00 \\
\hline \multicolumn{6}{|l|}{ M (maximum indemnification) } \\
\hline$C R_{o b s}$ ins. & . & 163.14 & 137.38 & 154.56 & 163.14 \\
\hline$B C R_{o b s}$ ins. & . & 231.84 & 240.42 & 223.25 & 154.56 \\
\hline$C R_{\text {siva }}$ ins. & . & 137.38 & 163.14 & 171.73 & 180.32 \\
\hline$B C R_{\text {siva }}$ ins. & . & 120.21 & 145.97 & 154.56 & 163.14 \\
\hline$W A C R_{\text {siva }}$ ins. & . & 145.97 & 171.73 & 171.73 & 171.73 \\
\hline$W A B C R_{\text {siva }}$ ins. & . & 145.97 & 171.73 & 171.73 & 171.73 \\
\hline
\end{tabular}


Table 12: Average income gain of index insurance calibrated on village average yields values and tested on the whole sample

\begin{tabular}{|c|c|c|c|c|c|}
\hline & $\rho=.5$ & $\rho=1$ & $\rho=2$ & $\rho=3$ & $\rho=4$ \\
\hline \multicolumn{6}{|l|}{ Strike } \\
\hline$C R_{\text {obs }}$ ins. & . & 370.46 & 395.87 & 395.87 & 388.98 \\
\hline$B C R_{\text {obs }}$ ins. & . & 359.00 & 359.00 & 359.00 & 359.00 \\
\hline$C R_{\text {siva }}$ ins. & 171.00 & 349.73 & 349.73 & 349.73 & 375.08 \\
\hline$B C R_{\text {siva }}$ ins. & . & 319.79 & 319.79 & 319.79 & 319.79 \\
\hline$W A C R_{\text {siva }}$ ins. & . & 219.17 & 219.17 & 219.17 & 219.17 \\
\hline $\begin{array}{l}W A B C R_{\text {siva }} \text { ins. } \\
\text { percentage of indemnified growers }\end{array}$ & . & 196.92 & 196.92 & 196.92 & 196.92 \\
\hline$C R_{o b s}$ ins. & 0.00 & 0.08 & 0.18 & 0.18 & 0.16 \\
\hline$B C R_{o b s}$ ins. & 0.00 & 0.15 & 0.15 & 0.15 & 0.15 \\
\hline$C R_{\text {siva }}$ ins. & 0.12 & 0.12 & 0.12 & 0.12 & 0.29 \\
\hline$B C R_{\text {siva }}$ ins. & 0.04 & 0.17 & 0.17 & 0.17 & 0.17 \\
\hline$W A C R_{\text {siva }}$ ins. & 0.00 & 0.19 & 0.19 & 0.19 & 0.19 \\
\hline$W A B C R_{\text {siva }}$ ins. & 0.00 & 0.19 & 0.19 & 0.19 & 0.19 \\
\hline \multicolumn{6}{|l|}{$\lambda$ (slope related parameter) } \\
\hline$C R_{o b s}$ ins. & . & 1.00 & 1.00 & 1.00 & 1.00 \\
\hline$B C R_{\text {obs }}$ ins. & . & 1.00 & 1.00 & 1.00 & 1.00 \\
\hline$C R_{\text {siva }}$ ins. & 1.00 & 1.00 & 1.00 & 1.00 & 1.00 \\
\hline$B C R_{\text {siva }}$ ins. & . & 1.00 & 1.00 & 1.00 & 1.00 \\
\hline$W A C R_{\text {siva }}$ ins. & . & 1.00 & 1.00 & 1.00 & 1.00 \\
\hline$W A B C R_{\text {siva }}$ ins. & . & 1.00 & 1.00 & 1.00 & 1.00 \\
\hline \multicolumn{6}{|l|}{ M (maximum indemnification) } \\
\hline$C R_{\text {obs }}$ ins. & . & 163.14 & 137.38 & 154.56 & 163.14 \\
\hline$B C R_{\text {obs }}$ ins. & . & 137.38 & 163.14 & 171.73 & 180.32 \\
\hline$C R_{\text {siva }}$ ins. & 180.32 & 231.84 & 240.42 & 223.25 & 154.56 \\
\hline$B C R_{\text {siva }}$ ins. & . & 120.21 & 145.97 & 154.56 & 163.14 \\
\hline$W A C R_{\text {siva }}$ ins. & . & 145.97 & 171.73 & 171.73 & 171.73 \\
\hline$W A B C R_{\text {siva }}$ ins. & . & 145.97 & 171.73 & 171.73 & 171.73 \\
\hline
\end{tabular}




\subsection{Out of sample calibrations}

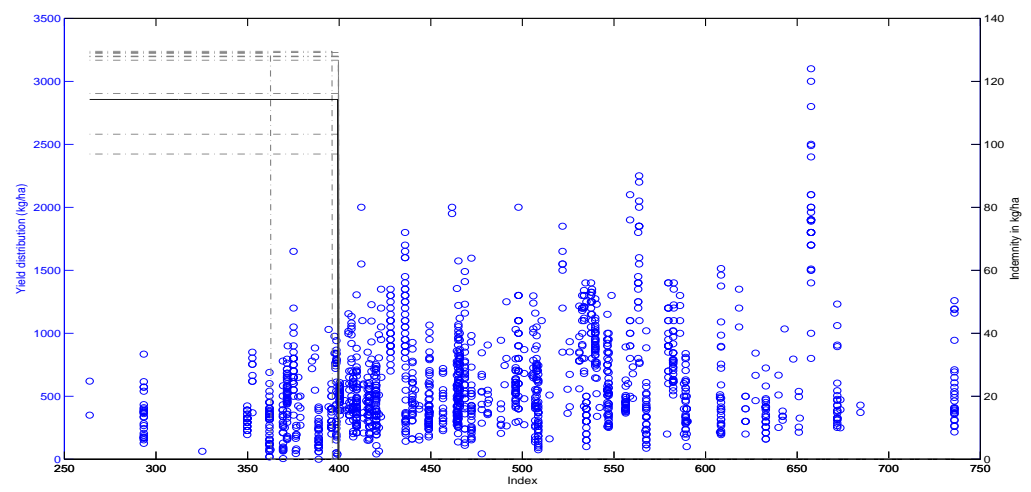

Figure 3: In-sample (solid line) and out-of-sample (dotted lines) indemnity schedules (kg/ha) for $C R_{o b s}$ insurance, for $\rho=2$ and scatter plot of yield distribution across index.

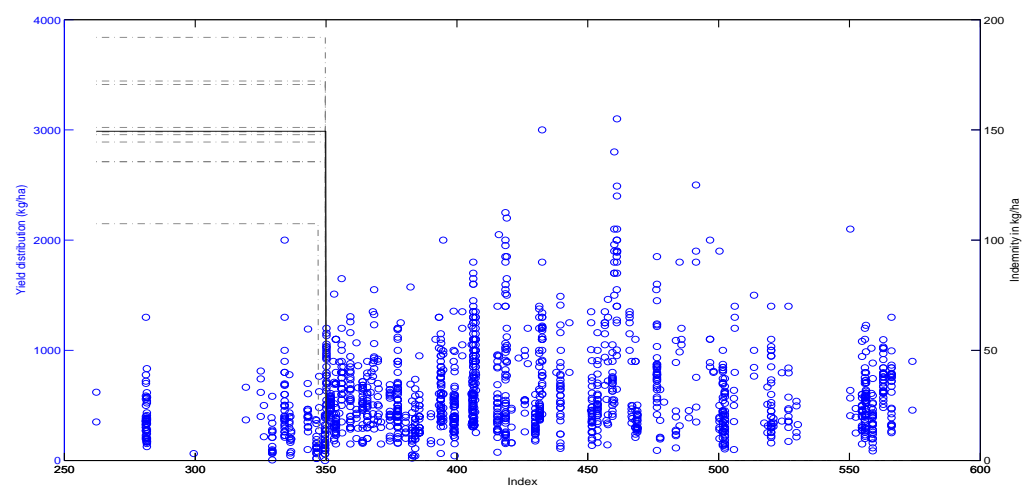

Figure 4: In-sample (solid line) and out-of-sample (dotted lines) indemnity schedules (kg/ha) for $B C R_{o b s}$ insurance, for $\rho=2$ and scatter plot of yield distribution across index.

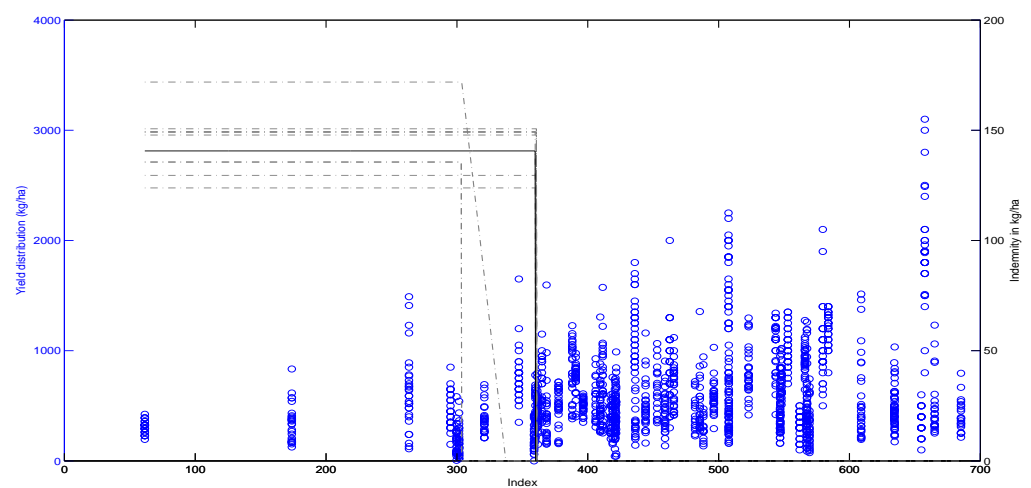

Figure 5: In-sample (solid line) and out-of-sample (dotted lines) indemnity schedules (kg/ha) for $C R_{\text {siva }}$ insurance, for $\rho=2$ and scatter plot of yield distribution across index. 


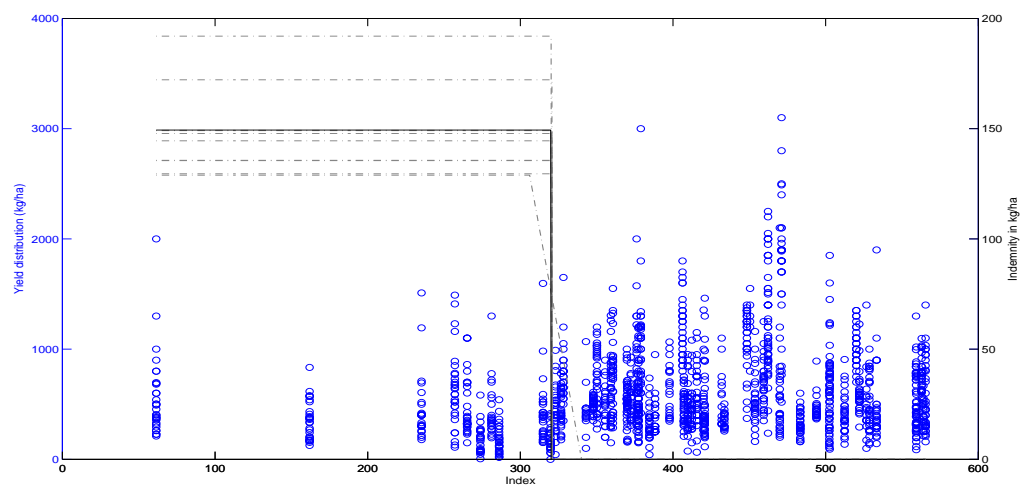

Figure 6: In-sample (solid line) and out-of-sample (dotted lines) indemnity schedules (kg/ha) for $B C R_{\text {siva }}$ insurance, for $\rho=2$ and scatter plot of yield distribution across index.

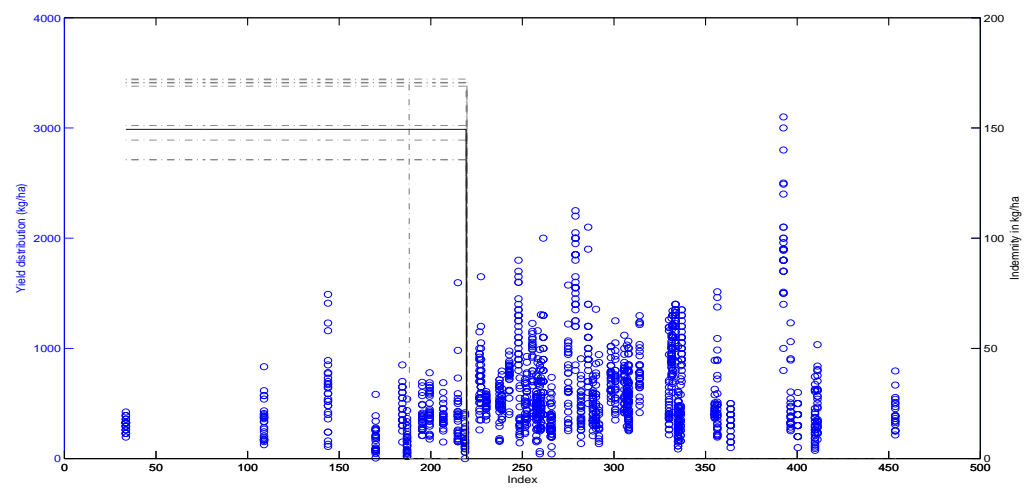

Figure 7: In-sample (solid line) and out-of-sample (dotted lines) indemnity schedules ( $\mathrm{kg} / \mathrm{ha}$ ) for $W A C R_{\text {siva }}$ insurance, for $\rho=2$ and scatter plot of yield distribution across index.

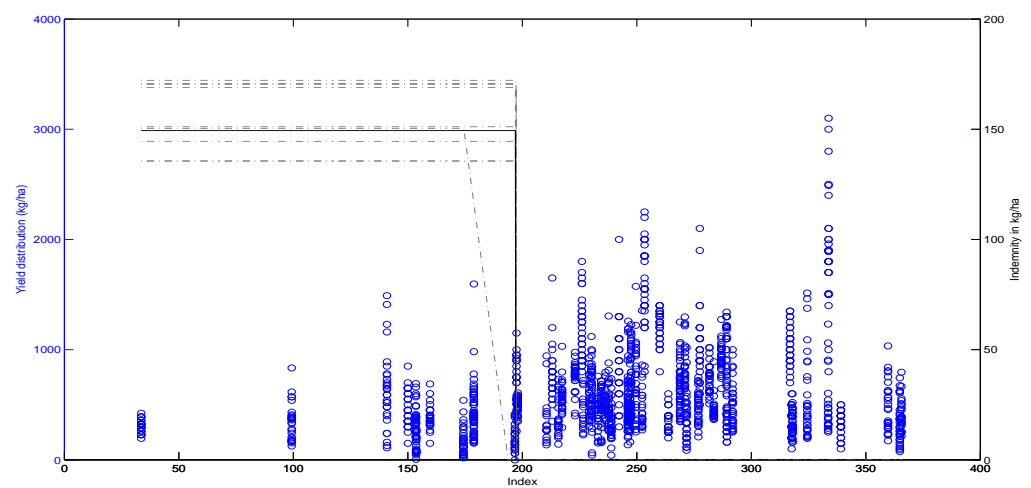

Figure 8: In-sample (solid line) and out-of-sample (dotted lines) indemnity schedules ( $\mathrm{kg} / \mathrm{ha}$ ) for $W A B C R_{\text {siva }}$ insurance, for $\rho=2$ and scatter plot of yield distribution across index. 


\subsection{Incentive to use costly inputs}

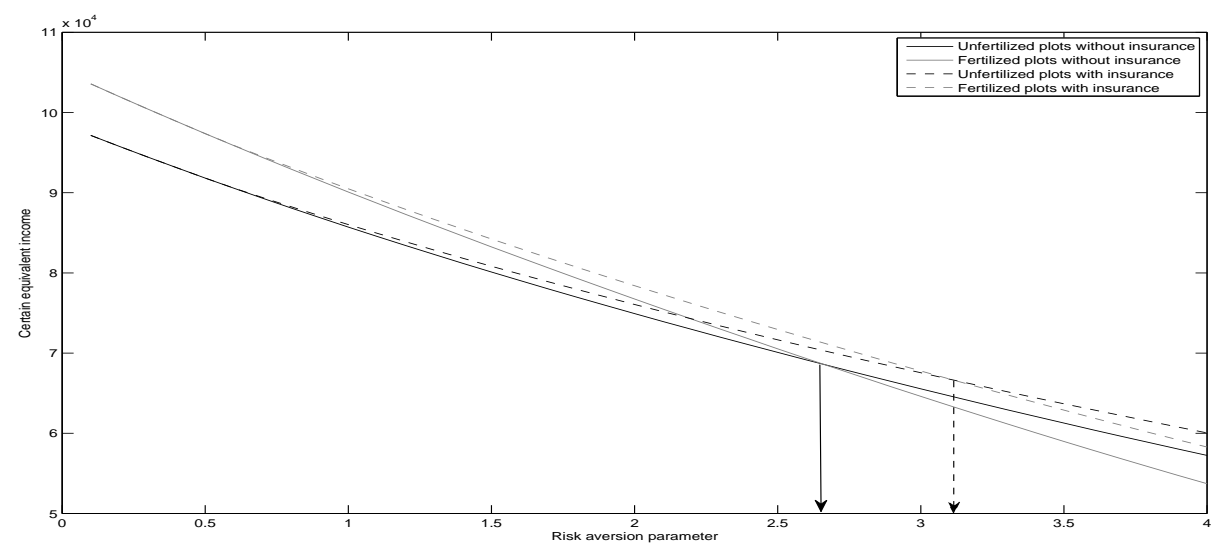

Figure 9: CEI without and with $B C R_{\text {obs }}$ based insurance, depending on risk aversion parameter, $\rho$, and technical itineraries.

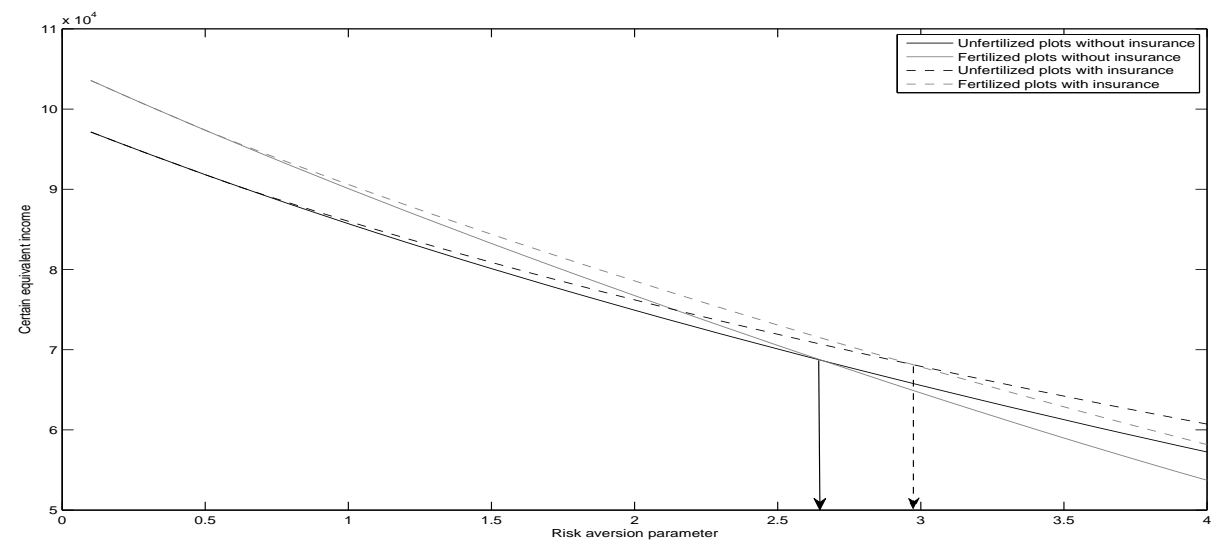

Figure 10: CEI without and with $C R_{\text {siva }}$ based insurance, depending on risk aversion parameter, $\rho$, and technical itineraries. 


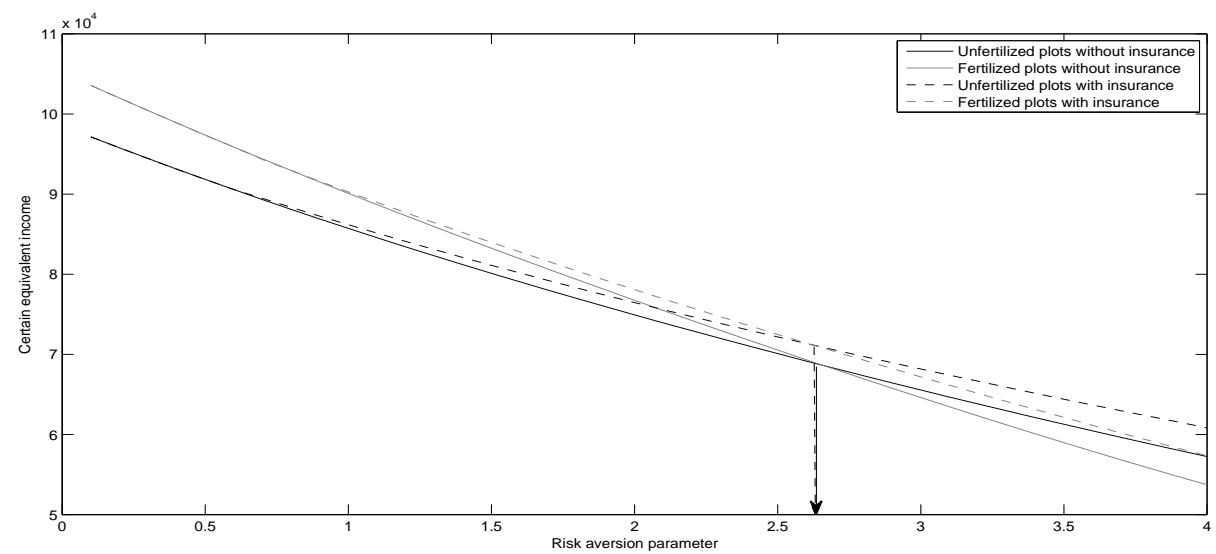

Figure 11: CEI without and with $B C R_{\text {siva }}$ based insurance, depending on risk aversion parameter, $\rho$, and technical itineraries.

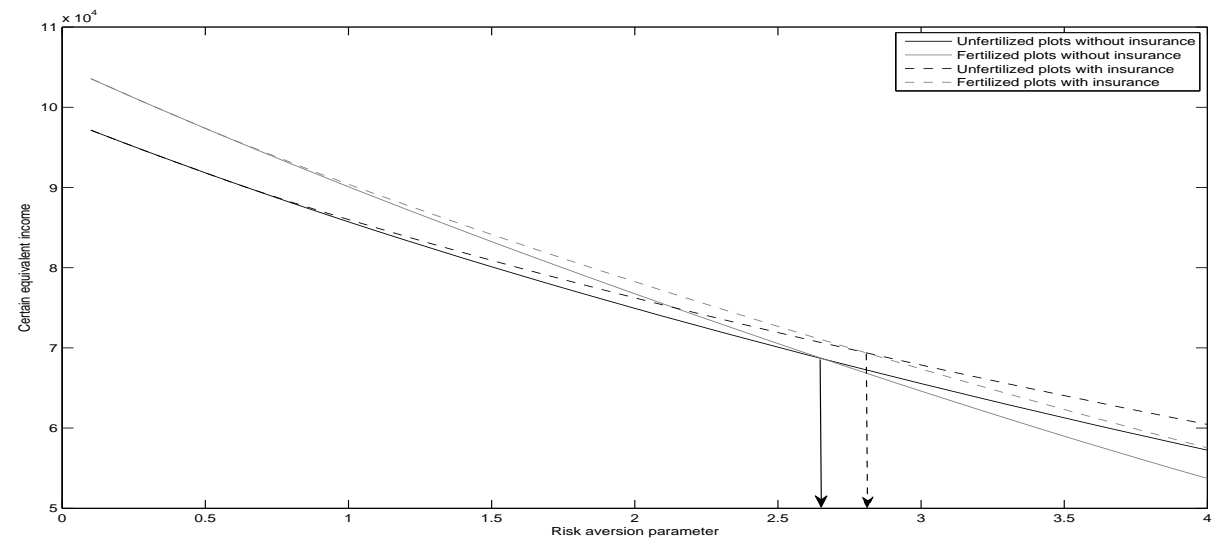

Figure 12: CEI without and with $W A C R_{\text {siva }}$ based insurance, depending on risk aversion parameter, $\rho$, and technical itineraries.

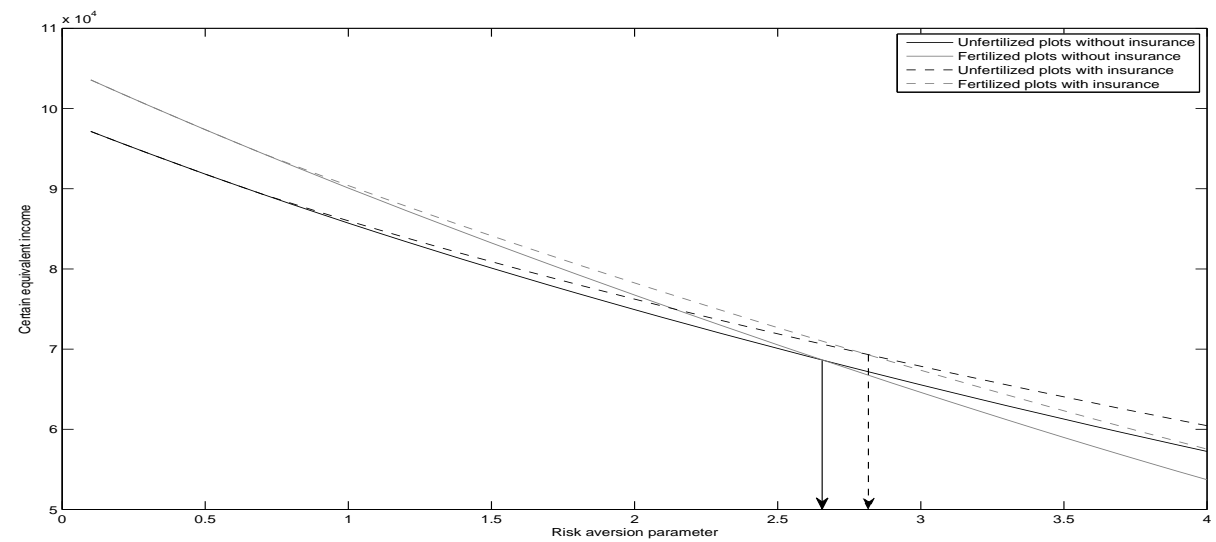

Figure 13: CEI without and with $W A B C R_{\text {siva }}$ based insurance, depending on risk aversion parameter, $\rho$, and technical itineraries. 